\title{
Systemic inflammatory response indicators in rabbits (Oryctolagus cuniculus) experimentally infected with sporulated oocysts of Eimeria stiedai (Apicomplexa: Eimeriidae)
}

Indicadores da resposta inflamatória sistêmica em coelhos (Oryctolagus cuniculus) infectados experimentalmente com oocistos esporulados de Eimeria stiedai (Apicomplexa: Eimeriidae)

Fagner Luiz da Costa Freitas ${ }^{1 *}$; Beatriz Lie Yamamoto²; Wagner Luiz da Costa Freitas 3 ; Jose Jurandir Fagliari Katyane de Sousa Almeida ${ }^{1}$; Rosangela Zacarias Machado ${ }^{4}$; Celio Raimundo Machado ${ }^{4}$

${ }^{1}$ School of Veterinary Medicine and Zootechnics, Federal University of Tocantins - UFT

${ }^{2}$ Postgraduate Program on Experimental Epidemiology Applied to Zoonoses, University of São Paulo - USP

${ }^{3}$ Postgraduate Program on Industrial Biotechnology, University of São Paulo - USP

${ }^{4}$ School of Agrarian and Veterinary Sciences, São Paulo State University - UNESP

Received October 25, 2010

Accepted November 11, 2010

\begin{abstract}
Hemograms and acute-phase proteins in adult male New Zealand White rabbits that had been experimentally infected orally with sporulated oocysts of Eimeria stiedai were evaluated over a 28-day period. Fifty animals were used, divided into two groups: group A infected with $1 \times 10^{4}$ sporulated oocysts of E. stiedai and group B inoculated with distilled water. On the seventh day after infection, the infected animals presented anemia and leukocytosis with neutrophilia and monocytosis. Protein fractionation by means of electrophoresis identified 19 acute-phase proteins with molecular weights ranging from 24 to $238 \mathrm{kD}$. Ceruloplasmin, transferrin and haptoglobin showed high levels on the seventh day after infection, with gradual increases in their concentrations until the end of the experimental period. Thus, from the data of the present study, E. stiedai is considered to be a pyogenic etiological agent for which the infection level can be monitored through the leukocyte count and serum concentrations of ceruloplasmin, transferrin and haptoglobin, and these can be recommended as complementary tests.
\end{abstract}

Keywords: Eimeria stiedai, acute-phase proteins, Oryctolagus cuniculus.

\section{Resumo}

O hemograma e proteínas de fase aguda foram avaliados durante 28 dias em coelhos adultos, machos, raça branco Nova Zelândia, infectados experimentalmente, via oral, com oocistos esporulados de Eimeria stiedai. Foram usados 50 animais distribuídos em dois grupos: grupo A infectado com $1 \times 10^{4}$ oocistos esporulados de E. stiedai e grupo B inoculado com água destilada. No 7 o dia após a infecçáo (dpi), os animais infectados tiveram anemia, leucocitose com neutrofilia e monocitose. O método de fracionamento de proteínas por eletroforese identificou 19 proteínas de fase aguda com pesos moleculares que variaram entre 24 e $238 \mathrm{kD}$. A ceruloplasmina, transferrina e haptoglobina tiveram níveis elevados no $7^{\circ} \mathrm{dpi}$ com aumento progressivo de suas concentraçóes até o término do período experimental. Desta forma, considerando-se os dados encontrados no presente estudo, E. stiedai é considerado um agente etiológico piogênico que pode ter sua infecção monitorada por determinação do leucograma e das concentraçóes séricas de ceruloplasmina, transferrina e haptoglobina, podendo ser estes recomendados como exames complementares.

Palavras-chave: Eimeria stiedai, proteínas de fase aguda, Oryctolagus cuniculus. 


\section{Introduction}

Hepatic coccidiosis is a disease caused by the protozoan Eimeria stiedai, and it is considered to be the most important disease faced by rabbit breeders, because of its high morbidity and mortality (GIORGI, 1968; CARDOSO; GUIMARÃES JR., 1993). Young rabbits are more susceptible to infection. The clinical condition generally observed is characterized by anorexia and diminished live and carcass weights, caused mainly by decreased food intake over the first four weeks. The condition may progress to death, which is attributed to the hepatic lesions that are also associated with the infection (GOMEZ-BAUTISTA et al., 1986). In the study conducted by Freitas et al. (2009), infection due to E. stiedai caused ascites, hepatomegaly associated with congestion and fibrosis, thickening of the bladder wall and retention of bile.

Consequent to injury, trauma or tissue infection, hosts develop a complex series of reactions that have the purpose of inhibiting continuation of the tissue damage through isolating and destroying the etiological agent and activating the repair process needed for functional activity to return to normal conditions (BAUMANN; GAULDIE, 1994). Over this period, a broad spectrum of mediators is released by tissue macrophages and blood monocytes. Among these, cytokines, and particularly tumor necrosis factor (TNF) and interleukins IL-1 and IL-6, are the main mediators for synthesis of acute-phase serum proteins (GRUYS et al., 1994; SINGH; PACHAURI, 2002; BILATE, 2007).

These proteins can be classified as positive, represented by ceruloplasmin, fibrinogen, C-reactive protein, antitrypsin and haptoglobin, and as negative, such as pre-albumin, albumin and transferrin (KANEKO et al., 2008). The functions of positive acute-phase proteins remain somewhat unclear, although some functions have been attributed to them, such as opsonization and capture of microorganisms and their products, activation of the complement system, neutralization of enzymes, binding to hemoglobin and free radicals and modulation of the immune response (GRUYS et al., 2005).

Depending on the animal species, acute-phase proteins may be considered to be more faithful indicators of the systemic response to inflammatory and infectious processes than other variables such as fever, increased erythrocyte sedimentation rate and presence of leukocytosis in association with neutrophilia (JAIN, 1989; FELDMAN, et al., 2000). In clinical practice, methods for detecting acute-phase proteins have assisted in diagnosing inflammatory processes (PATELLI et al., 2008). Some comparative studies have indicated that these proteins are more sensitive for detecting inflammation, in relation to hematological analyses (HORADAGODA et al., 1999). However, hemograms have notable importance for diagnosing and controlling the evolution of infectious and chronic diseases and may also enable analysis on the quantitative and morphological variations of blood series.

The present study had the aim of evaluating the hematological profile and acute-phase protein concentrations in rabbits that were infected experimentally with sporulated oocysts of $E$. stiedai.

\section{Material and Methods}

This study was developed in the Department of Veterinary Pathology, School of Agrarian and Veterinary Sciences (FCAV), São Paulo State University (UNESP), Jaboticabal campus, State of São Paulo. To obtain the oocysts, two adult male New Zealand White rabbits that had been subjected to immunosuppression through administration of dexamethasone ( $0.5 \mathrm{mg} \cdot \mathrm{kg}^{-1}$, intramuscularly) were used.

After immunosuppression had been achieved, the animals were infected orally with $1 \times 10^{5}$ sporulated oocysts of Eimeria stiedai. On the $12^{\text {th }}$ day after inoculation with the oocysts, the animals were sacrificed. Following this, by means of gallbladder puncture, the oocysts needed for carrying out the experiment were obtained. These were subjected to sporulation in $2.5 \%$ potassium dichromate at room temperature for 48 hours.

The experiment was conducted using 50 male New Zealand White rabbits of between 40 and 50 days of age and similar weights. The animals were grouped randomly into two groups (A - Infected; and $\mathrm{B}$ - Control), which were each composed of 25 rabbits that were kept in separate locations but under the same management conditions. The feeding and drinking troughs used contained balanced animal feed and clean water without anticoccidian agents, respectively. The feeding and drinking troughs were washed with neutral detergent and flame-treated every 24 hours in order to avoid the risk of reinfection. For the inoculation, all the animals in the experiment were physically restrained and inoculated orogastrically with the aid of a probe. The animals in group A were inoculated with $1.0 \mathrm{~mL}$ of physiological solution containing $1 \times 10^{4}$ sporulated oocysts of $E$. stiedai, while group B was inoculated only with $1.0 \mathrm{~mL}$ of physiological solution.

Blood samples were collected on the day of inoculation and on the $7^{\text {th }}, 14^{\text {th }}, 21^{\text {st }}$ and $28^{\text {th }}$ days afterwards, by means of cardiac puncture using needles of size $25 \times 8$ and sterile syringes of capacity $10 \mathrm{~mL}$. These samples were then divided: $2 \mathrm{~mL}$ was placed in a test tube containing ethylenediaminetetraacetic acid (sodium EDTA) in order to produce a hemogram; and $8 \mathrm{~mL}$ was placed in a test tube without anticoagulant in order to obtain serum after centrifugation. The material was sent to the Research Laboratory of the Department of Veterinary Surgery and Clinical Practice, FCAV/UNESP, in Jaboticabal, SP, for hematological and biochemical tests to be performed.

Total erythrocyte and leukocyte counts were performed using an automated cell counter (CC-Celm ${ }^{\circ}$, Barueri, SP); hemoglobin concentrations were determined by means of the cyanmethemoglobin method, using a commercial kit (Labtest ${ }^{\circ}$ Diagnóstica, Belo Horizonte, MG); and readings were made in a spectrophotometer (LabQuest ${ }^{\circ}$ Diagnóstica, Belo Horizonte, MG). Hematocrit was determined by means of the microhematocrit technique, with centrifugation in capillary tubes at 12,000 rpm for five minutes. The mean corpuscular volume and the mean corpuscular hemoglobin concentration were calculated as described by Wintrobe (1932). Differential leukocyte counts were performed on blood smears stained with Rosenfeld solution. One hundred cells were counted under the microscope and the results were given as absolute values and subsequently transformed into relative values. 
The serum total protein concentration was determined by means of the Biureto method, using a commercial kit (Labtest ${ }^{\oplus}$ Diagnóstica, Belo Horizonte, MG). To fractionate the proteins, electrophoresis on polyacrylamide gel containing sodium dodecyl sulfate (SDS-PAGE) was used in accordance with the technique described by Laemmli (1970). After fractionation, the gel was stained in Coomassie blue solution for 10 minutes and was then placed in a $7 \%$ acetic acid solution to remove the excess staining material, until the protein fractions could be seen clearly. The concentrations of these proteins were determined using a computerized densitometer (Shimadzu CS 9301, Tokyo, Japan). Marker solutions (Sigma, Saint Louis, USA) with molecular weights of 36,000, 45,000, 66,000, 97,400, 116,000 and 205,000 daltons (D) were used as the reference, along with purified haptoglobin and alpha-1-antitrypsin proteins. The data obtained were evaluated using Wilcoxon's test with a 5\% significance level. This study was conducted in accordance with the resolutions of the Ethics, Bioethics and Animal Wellbeing Committee (CEBEA) of FCAV/UNESP.

\section{Results and Discussion}

Table 1 shows that on the seventh day after infection, the infected animals presented mild anemia due to decreased hematocrit and hemoglobin concentration. There was leukocytosis because of the presence of neutrophilia and also slight monocytosis on the $28^{\text {th }}$ day after infection. The lymphocyte, eosinophil and basophil counts remained unchanged throughout the period of the experiment. In the study developed by Çam et al. (2008), lymphopenia was observed on the $24^{\text {th }}$ day after infection and leukocytosis on the $16^{\text {th }}$ and $24^{\text {th }}$ days because of increased presence of neutrophils. Their study also found reduced hematocrit, hemoglobin and mean corpuscular volume levels on the $24^{\text {th }}$ day after infection, thereby characterizing normochromic microcytic anemia.

The protein fractionation method using electrophoresis made it possible to identify 19 acute-phase proteins with molecular weights ranging from 24 to $238 \mathrm{kD}$. Of these, nine were identified by name, as follows: antitrypsin, ceruloplasmin, alpha-1-glycoprotein acid, haptoglobin, transferrin, albumin, IgA, light-chain IgG and heavy-chain IgG. Most of the acute-phase proteins presented oscillations during the period of the experiment, but ceruloplasmin, transferrin and haptoglobin presented high levels on the seventh day after infection with progressive increases in their concentrations thereafter. The proteins with molecular weights of 24, 115 and $175 \mathrm{kD}$, and the proteins IgA, heavy-chain IgG and albumin did not present significant changes (Table 2).

With regard to acute-phase proteins, it is important to recognize that they become elevated in animals with different diseases. They are nonspecific for diagnosing the causes of diseases and therefore are not used as primary diagnostic tools (CERÓN, et al., 2005). However, they have high sensitivity for determining the presence of inflammation or subclinical infection. From a practical point of view, it is more convenient and more reliable to determine the serum concentrations of acute-phase proteins than to determine the concentrations of factors and cytokines such as TNF, IL-1 and IL-6 that are responsible for increased levels of acute-phase proteins. These factors and cytokines present short half-lives and have to be

Table 1. Blood component concentrations in control rabbits (Oryctolagus cuniculus) and rabbits experimentally infected with $1 \times 10^{4}$ sporulated oocysts of Eimeria stiedai.

\begin{tabular}{|c|c|c|c|c|c|}
\hline \multirow[t]{2}{*}{ Parameters } & \multicolumn{5}{|c|}{ Days after infection } \\
\hline & $\mathbf{0}$ & 7 & 14 & 21 & 28 \\
\hline \multicolumn{6}{|c|}{ Erythrocytes $\left(\times 10^{6} / \mathrm{mm}^{-3}\right)$} \\
\hline Control & $4.86^{\mathrm{ns}}(4.83-5.02)$ & $4.91^{\mathrm{ns}}(4.36-5.02)$ & $5.00^{\mathrm{ns}}(4.48-5.08)$ & $5.00^{\mathrm{a}}(6.64-8.28)$ & $5.11^{\text {ns }}(4.81-5.50)$ \\
\hline Infected & $4.84^{\mathrm{ns}}(4.60-5.02)$ & $5.01^{\mathrm{ns}}(4.33-5.55)$ & $5.39^{\text {ns }}(4.50-5.59)$ & $3.18^{\mathrm{b}}(1.80-4.48)$ & $4.90^{\text {ns }}(4.19-5.67)$ \\
\hline \multicolumn{6}{|c|}{ Hemoglobin $\left(\mathrm{mg} \mathrm{dL}^{-1}\right)$} \\
\hline Control & $11.72^{\text {ns }}(10.70-12.70)$ & $12.54^{\mathrm{a}}(11.7-13.80)$ & $12.02^{\mathrm{ns}}(10.90-12.70)$ & $7.94^{\mathrm{b}}(5.00-11.80)$ & $12.05^{\mathrm{ns}}(11.00-13.20)$ \\
\hline Control & $39.00^{\text {ns }}(38.00-41.00)$ & $39.80^{\mathrm{a}}(38.00-43.00)$ & $39.40^{\text {ns }}(36.00-43.00)$ & $38.80^{\mathrm{a}}(35.00-40.00)$ & $38.50^{\mathrm{ns}}(36.00-42.00)$ \\
\hline Infected & $39.06^{\text {ns }}(37.00-41.00)$ & $35.00^{\mathrm{b}}(32.00-38.00)$ & $38.80^{\text {ns }}(35.00-44.00)$ & $26.00^{\mathrm{b}}(15.00-39.00)$ & $36.00^{\text {ns }}(33.00-42.00)$ \\
\hline \multicolumn{6}{|l|}{$\begin{array}{l}\text { Mean corpuscular } \\
\text { volume }(\mathrm{f} \mathrm{L})\end{array}$} \\
\hline Control & $8.02^{\text {ns }}(7.57-8.49)$ & $8.14^{a}(7.73-8.68)$ & $7.88^{a}(7.55-8.08)$ & $7.77^{\mathrm{b}}(7.44-8.25)$ & $7.54^{\mathrm{a}}(7.44-7.64)$ \\
\hline Infected & $3.90^{\mathrm{ns}}(3.40-4.20)$ & $6.10^{\mathrm{a}}(4.00-9.20)$ & $4.98^{\text {ns }}(4.20-6.10)$ & $4.98^{\mathrm{ns}}(3.90-6.50)$ & $8.00^{\mathrm{a}}(5.70-10.80)$ \\
\hline \multicolumn{6}{|l|}{ Neutrophils $\left(/ \mathrm{mm}^{3}\right)$} \\
\hline Control & $1.07^{\mathrm{ns}}(0.32-2.44)$ & $0.92^{b}(0.51-1.39)$ & $1.04^{\mathrm{ns}}(0.60-1.22)$ & $1.51^{\mathrm{b}}(0.79-2.93)$ & $1.89^{\mathrm{b}}(1.04-4.10)$ \\
\hline Infected & $1.18^{\text {ns }}(1.01-1.28)$ & $2.15^{\mathrm{a}}(1.20-3.37)$ & $1.33^{\text {ns }}(0.76-2.87)$ & $3.77^{\mathrm{a}}(2.02-10.53)$ & $4.13^{\mathrm{a}}(2.10-8.42)$ \\
\hline \multicolumn{6}{|l|}{ Monocytes $\left(/ \mathrm{mm}^{3}\right)$} \\
\hline Control & $0.03^{\text {ns }}(0.00-0.08)$ & $0.02^{\mathrm{ns}}(0.00-0.18)$ & $0.02^{\mathrm{ns}}(0.00-0.05)$ & $0.05^{\text {ns }}(0.00-0.10)$ & $0.04^{\mathrm{b}}(0.00-0.05)$ \\
\hline Infected & $0.04^{\text {ns }}(0.00-0.08)$ & $0.07^{\text {ns }}(0.00-0.07)$ & $0.03^{\text {ns }}(0.00-0.05)$ & $0.03^{\text {ns }}(0.00-0.07)$ & $0.09^{\mathrm{a}}(0.06-0.11)$ \\
\hline
\end{tabular}

ns: not significant according to Wilcoxon's test at the probability level of $5 \%$. Means followed by the same letter did not differ statistically. 
Table 2. Acute-phase protein levels (mg.dL $\left.{ }^{-1}\right)$ in control rabbits (Oryctolagus cuniculus) and rabbits experimentally infected with $1 \times 10^{4}$ sporulated oocysts of Eimeria stiedai.

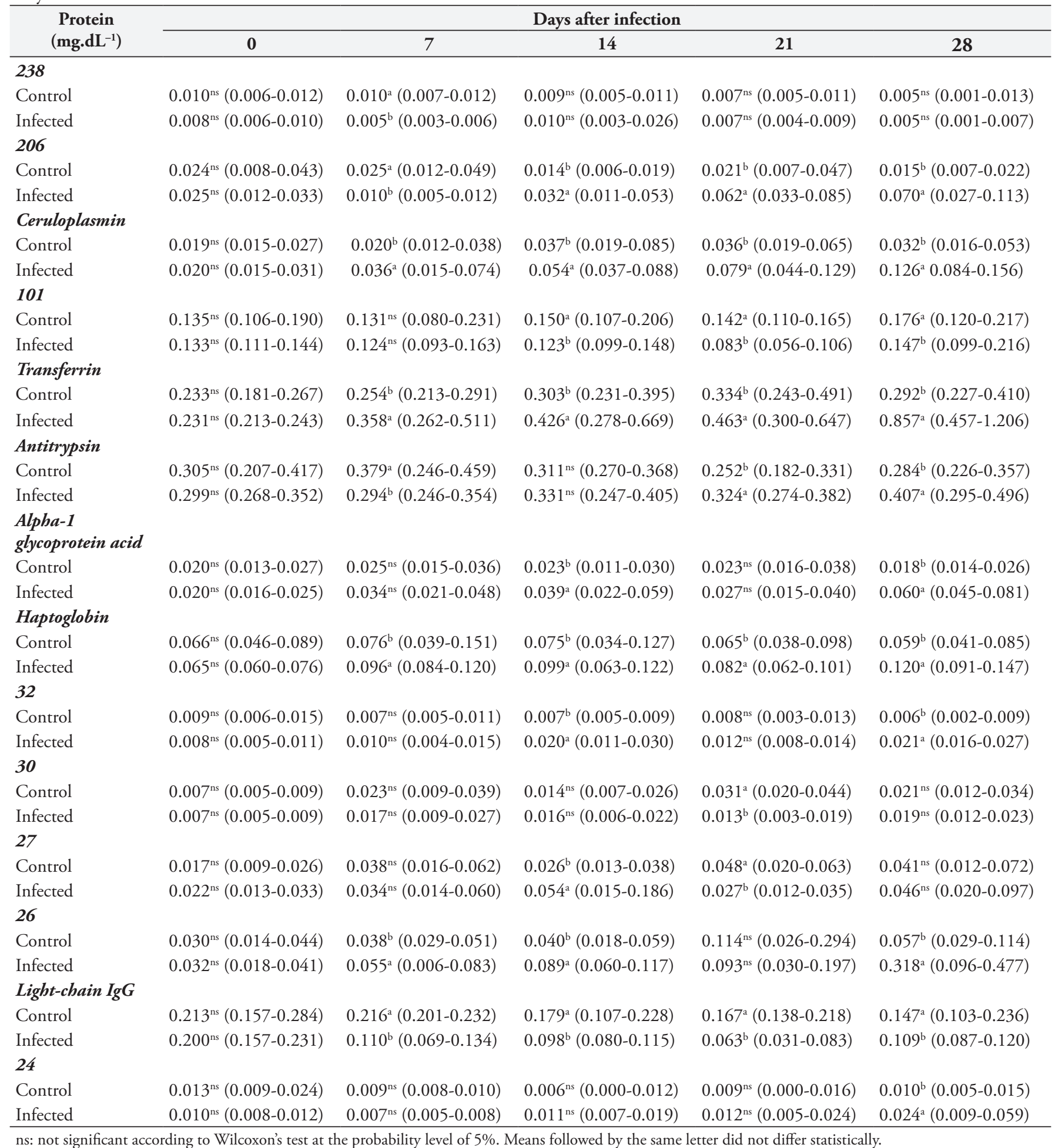

measured using more sophisticated methods (GRANINGER et al., 1992; GIANAZZA et al., 2002).

It needs to be borne in mind that interpretation of the laboratory results also requires careful correlation with the animal's clinical history and physical examination, given that inflammatory or infectious processes raise the baseline concentrations of certain biochemical indicators that are important for clinical assessments.
From a biochemical point of view, the animals in the present experiment presented elevated concentrations of bilirubin, aspartate aminotransferase, alanine aminotransferase, alkaline phosphatase and gamma-glutamyl transferase (FREITAS et al., 2009). In the same study, these authors observed ascites, hepatomegaly associated with congestion and fibrosis, thickening of the bladder wall and bile retention. There was also hyperplasia and dilatation of the bile 
ducts, with papilliferous intraluminal projections due to intense mitotic activity and considerable presence of parasitic structures. Furthermore, proliferation of connective tissue and mononuclear inflammatory cell infiltrate were also observed in the ducts, as well as hepatic congestion and moderate vacuolar degeneration of the hepatocytes. These lesions resulting from parasitism were certainly responsible for the elevations in acute-phase protein concentrations found in the present experiment.

Transferrin is considered to be a negative acute-phase protein, in that its levels tend to decrease under inflammatory conditions (SINGH; PACHAURI, 2002). However, in the present study, the transferrin concentrations remained high throughout the period of the experiment. This was similar to the results observed in goats that were infected experimentally with Trypanosoma evansi (PATELLI et al., 2008) and sheep infected with T. vivax (ALMEIDA, 2007). Transferrin is a beta globulin synthesized by hepatic cells, and its function is related to transportation of plasma iron, with antibacterial and antiviral activity, and its plasma concentration increases in cases of iron deficiency and during pregnancy (KANEKO et al., 2008). Interleukin-1 produced by macrophages stimulates the secretion of transferrin and haptoglobin by hepatocytes, with increased incorporation of iron inside the liver, thereby reducing the availability of iron (TIZARD, 2008). In addition, transferrin levels may increase in cases of liver disease and nephrotic syndrome and may decrease in cases of iron storage disease (ECKERSALL et al., 2008). Haptoglobin binds strongly with hemoglobin, with an anti-inflammatory capacity and the ability to bind to the integrins CD11b and CD18 (EL GHMATI et al., 1996), which are the main membrane receptors present on the surface of leukocyte membranes (GRUYS et al., 2005)

Studies like the present one have made it possible to suggest what type of infection is occurring in the animal under evaluation, as shown by the observed changes to specific acute-phase proteins. Several such studies have now been conducted on dogs, and the proteins that become elevated in cases of babesiosis, leishmaniasis, parvovirus and infections due to Bordetella bronchiseptica, Ehrlichia canis and Escherichia coli have been ascertained. This makes it possible to start to treat the condition before clinical worsening occurs (CERÓN et al., 2005). Fagliari et al. (2003) also observed that two hours after calves had been infected with Mannheimia (Pasteurella) haemolytica, the levels of ceruloplasmin, alpha-1antitrypsin, haptoglobin and glycoprotein acid became elevated. This suggested that assays on these proteins could be used to detect preclinical disease. Acute-phase proteins have been evaluated in cattle with mastitis (ECKERSALL et al., 2001), cattle with theileriosis (GLASS et al., 2003) and horses with influenza (HULTÉN et al., 1999). In this respect, studies conducted on human beings have reported increased levels of acute-phase proteins in patients with malaria (GRANINGER et al., 1992) and inflammatory and postoperative diseases (MURATSUBAKI et al., 2002), and have reported satisfactory use of electrophoresis for separation of protein $\mathrm{M}$ in patients with multiple myeloma (MIURA et al., 2000).

\section{Conclusion}

From the changes to hematological and biochemical parameters found in the present study, in rabbits experimentally challenged with E. stiedai, the latter is considered to be a pyogenic etiological agent for which the infection level can be monitored through the leukocyte count and serum concentrations of ceruloplasmin, transferrin and haptoglobin, and these can be recommended as complementary tests.

\section{References}

ALMEIDA, K. S. Alteraçóes clínicas, hematológicas, bioquímicas e histopatológicas em ovinos infectados experimentalmente com Trypanosoma vivax (Ziemann, 1905). 2007. 110 f. Tese (Doutorado)Universidade Estadual Paulista, Faculdade de Ciências Agrárias e Veterinária, Jaboticabal.

BAUMANN, H.; GAULDIE, J. The acute phase response. Immunology Today, v. 15, n. 2, p. 74-80, 1994. http://dx.doi.org/10.1016/01675699(94)90137-6

BILATE, A. M. B. Inflamação, citocinas, proteínas de fase aguda e implicações terapêuticas. Temas de Reumatologia Clínica, v. 8, n. 2, p. $47-51,2007$.

ÇAM, Y. et al. Eimeria stiedai: Experimental infection in rabbits and the effect of treatment with toltrazuril and ivermectin. Experimental Parasitology, v. 119, n. 1, p. 164-172, 2008.

CARDOSO, M. A.; GUIMARÃES JÚNIOR, J. S. Ocorrência de Eimeria spp em coelhos domésticos (Oryctolagus cuniculus) em quatro Municípios do Norte do Paraná. Semina: Ciências Agrárias, v. 14, n. 1, p. $12-16,1993$

CÉRON, J. J.; ECKERSALL, P. D.; MARTÍNEZ-SUBIELA, S. Acute phase proteins in dogs and cats: current knowledge and future perspectives. Veterinary Clinical Pathology, v. 34, n. 2, p. 85-99, 2005.

ECKERSALL, P. D. Proteins, Proteomics and the Dysproteinemias. In: KANEKO, J. J.; HARVEY, J. W.; BRUSS M. L. (Eds). Clinical biochemistry of domestic animals. 6th ed. Burlington: Academic Press, 2008. p.117-155. http://dx.doi.org/10.1016/B978-0-12-370491$7.00005-2$

ECKERSALL, P. D. et al. Acute phase proteins in serum and milk from dairy cows with clinical mastitis. Veterinary Record, v. 148, n. 2, p. 35-41, 2001. PMid:11202551. http://dx.doi.org/10.1136/vr.148.2.35

EL GHMATI, S. M. et al. Identification of haptoglobin as an alternative ligand for CD11b/CD18. The Journal of Immunology, v. 156, n. 7, p. 2542-2552, 1996.

FAGLIARI, J. J. et al. Serum protein concentrations in calves with experimentally induced pneumonic pasteurellosis. Arquivo Brasileiro de Medicina Veterinária e Zootecnia, v. 55, n. 4, p. 383-387, 2003. http://dx.doi.org/10.1590/S0102-09352003000400001

FELDMAN, B. F.; ZINKL, J. G.; JAIN, N. C. Schalm's veterinary hematology. $5^{\text {th }}$ ed. Philadelphia: Lippincot Willians \& Wilkins, 2000. $1344 \mathrm{p}$.

FREITAS, F. L. C. et al. Aspectos anatomopatológicos e bioquímicos da coccidiose hepática em coelhos. Revista de Patologia Tropical, v. 38, n. 2, p. 115-125, 2009.

GIANAZZA, E. et al. Monitoring the effects of drug treatment in rat models of disease by serum protein analysis. Journal of Chromatography B, v. 771, n. 1-2, p. 107-130, 2002. http://dx.doi. org/10.1016/S0378-4347(01)00562-X 
GIORGI, W. Doenças observadas em coelhos durante o quinqüênio 1963-1967, no Estado de São Paulo. Biológico, v. 34, n. 1, p. 71-82, 1968.

GLASS, E. J. et al. The protozoan parasite, Theileria annulata, induces a distinct acute phase protein response in cattle that is associated with pathology. International Journal Parasitology, v. 33, n. 12, p. 1409-1418, 2003. http://dx.doi.org/10.1016/S0020-7519(03)00166-8

GOMEZ-BAUTISTA, M.; GARCIA, M. V.; ROJO-VAZQUEZ, F. A. The levels of total protein fractions in the serum of rabbits infected with Eimeria stiedai. Annales de Parasitologie Humaine et Comparée, v. 61, n. 4, p. 393-400, 1986.

GRANINGER, W. et al. Serum protein concentrations in Plasmodium falciparum malaria. Acta Tropica, v. 52, n. 2-3, p. 121-128, 1992. http://dx.doi.org/10.1016/0001-706X(92)90027-U

GRUYS, E. et al. Acute phase reaction and acute phase proteins. Journal of Zhejiang University. Science B, v. 6, n. 11, p. 1045-1056, 2005. PMid:16252337. PMCid:1390650. http://dx.doi.org/10.1631/ jzus.2005.B1045

GRUYS, E.; OBWOLO, M. J.; TOUSSAINT, M. J. Diagnostic significance of the major acute phase proteins in veterinary clinical chemistry: a review. Veterinary Bulletin, v. 64, n. 11, p. 1009-1018, 1994.

HORADAGODA, N. U. et al. Acute phase proteins in cattle: discrimination between acute and chronic inflammation. Veterinary Record, v. 144, n. 16, p. 437-441, 1999. PMid:10343375. http://dx.doi. org/10.1136/vr.144.16.437

HULTÉN, C. et al. The acute phase protein amyloid A (SAA) as an inflammatory marker in equine influenza virus infection. Acta Veterinaria Scandinavica, v. 40, n. 4, p. 323-333, 1999.
JAIN, N. C. Acute phase proteins. In: KIRK, R. W. Current veterinary therapy X: small animal practice. Philadelphia: Saunders, 1989. p. $468-471$.

KANEKO, J. J.; HARVEY, J. W.; BRUSS, M. L. Clinical biochemistry of domestic animals. $6^{\text {th }}$ ed. Burlington: Academic Press, 2008.

LAEMMLI, U. K. Cleavage of structural proteins during the assembly of the head of bacteriophage T4. Nature, v. 227, n. 5259, p. 680-685, 1970. PMid:5432063. http://dx.doi.org/10.1038/227680a0

MIURA, T. et al. Detection of monoclonal proteins by capillary electrophoresis using a zwitterion in the running buffer. Clinica Chimica Acta, v. 299, n. 1-2, p. 87-99, 2000. http://dx.doi.org/10.1016/S00098981(00)00277-1

MURATSUBAKI, H. et al. Detection of serum proteins by native polyacrylamide gel electrophoresis using Blue Sepharose CL-6Bcontaining stacking gels. Analytical Biochemistry, v. 307, n. 2, p. 337-340, 2002. http://dx.doi.org/10.1016/S0003-2697(02)00052-0

PATELLI, T. H. C. et al. Perfil eletroforético das proteínas de fase aguda em caprinos experimentalmente infectados com Trypanosoma evansi. Brazilian Journal Veterinary Research and Animal Science, v. 45, suppl. 1, p. 481-487, 2008.

SINGH, S. V.; PACHAURI, S. P. Acute phase proteins in bovine mastitis. Indian Journal Animal Science, v. 72, n. 1, p. 20-22, 2002.

TIZARD, I. R. Veterinary Immunology: An Introduction. 8th ed. Philadelphia: Elsevier, 2008. p.147.

WINTROBE, M. M. The size and hemoglobin content of the erythrocyte. Methods of determination and clinical application. Journal of Laboratory and Clinical Medicine, v. 17, p.899-912, 1932. 